\title{
Range and conservation of the regionally Critically Endangered Black-collared Swallow, Pygochelidon melanoleuca (Wied, 1820) (Aves, Hirundinidae), in Minas Gerais, Brazil
}

\author{
Gabriele A. Silva, ${ }^{1}$ Gilberto N. Salvador, ${ }^{2}$ Gustavo B. Malacco, ${ }^{3}$ Wagner Nogueira, ${ }^{4}$ Sara M. \\ Almeida ${ }^{5}$
}

1 Universidade Federal de Uberlândia, Instituto de Biologia, Laboratório de Ornitologia e Bioacústica, Rua Ceará, CEP: 38.400-902, Uberlândia, MG, Brazil. 2 Universidade Federal do Pará, Instituto de Ciências Biológicas, Laboratório de Ecologia e Conservação, Rua Augusto Corrêa, CEP: 66.075-110, Belém, PA, Brazil. 3 Associação para a Gestão Socioambiental do Triângulo Mineiro (Angá), Avenida Anselmo Alves dos Santos, CEP: 38.408-008, Uberlândia, MG, Brazil. 4 Sustentar Meio Ambiente Ltda ME, Rua Queluz, CEP: 32.670-172, Betim, MG, Brazil. 5 Universidade Federal do Pará, Instituto de Ciências Biológicas, Museu de Zoologia de Vertebrados, Rua Augusto Corrêa, CEP: 66.075-110, Belém, PA, Brazil.

Corresponding author: Gabriele A. Silva, gabrieleandreia@hotmail.com

\begin{abstract}
The Black-collared Swallow, Pygochelidon melanoleuca, is a Critically Endangered species in the state of Minas Gerais, Brazil, where its distribution remains poorly known. Here we present novel occurrence records in the Paranaíba, São Francisco and Jequitinhonha river basins, and we discuss the conservation of this species in the region.
\end{abstract}

\section{Keywords}

Hirundinidae; hydroelectric power plants; Neotropics; São Francisco river basin.

Academic editor: Jeferson Vizentin-Bugoni | Received: 18 February 2017 | Accepted: 6 July 2017 | Published 22 September 2017

Citation: Silva GA, Salvador GN, Malacco GB, Nogueira W, Almeida SM (2017) Range and conservation of the regionally Critically Endangered Black-collared Swallow, Pygochelidon melanoleuca (Wied, 1820) (Aves, Hirundinidae), in Minas Gerais, Brazil. Check List 13 (5): $455-459$. https://doi.org/10.15560/13.5.455

\section{Introduction}

The Black-collared Swallow, Pygochelidon melanoleuca (Wied, 1820) (Aves, Hirundinidae), is restricted to riparian habitats especially near waterfalls and rapids, often perching on exposed rocks in the middle of such watercourses (Turner 2016). This species occurs from eastern Colombia to southern and eastern Venezuela, Guianas and northern Brazil, with scattered records in Paraguai and northern Argentina (Ridgely and Tudor 1989, Turner 2016). In Brazil, the species is rare throughout Amazonia (Ridgely and Tudor 1989, Sick 1997), with sparse records also from southeastern Bahia, southern Goiás, Pernambuco, Paraná (Ridgely and Tudor 1989, Sick 1997, Straube et al. 2004) and western Minas Gerais (Drummond et al. 2008).

Although $P$. melanolenca is globally classified as Least Concern (BirdLife International 2016), it is considered Near Threatened in Brazil (criterion A3c; MMA 2015), and Critically Endangered in the state of Minas Gerais (criterion A3c; Drummond et al. 2008; COPAM 2010). The main threat to this species is habitat loss due to the installation of hydroelectric dams (Drummond et al. 2008, MMA 2015, Lees et al. 2016). Here, we provide 
new distributional data for $P$. melanoleuca in Minas Gerais, where it is known to date from only a few records in the Paranaíba river basin (Drummond et al. 2008). Based on our findings we discuss perspectives for its conservation in this region.

\section{Methods}

To update the range of $P$. melanoleuca in Minas Gerais, we compiled recent records collected by ourselves and those obtained by personal communications with other ornithologists. We also gathered records from grey and published literature and ornithological collections, namely, the Instituto Nacional de Pesquisas da Amazônia (INPA), Museu Paraense Emílio Goeldi (MPEG), Museu de Zoologia of the Universidade de São Paulo (MZUSP), Museu Nacional do Rio de Janeiro (MNRJ) and Centro de Coleções Taxonômicas of the Universidade Federal de Minas Gerais (DZUFMG). We also compiled records available on the following online databases: WikiAves (http://www.wikiaves.com.br/), GBIF (http://www.gbif .org/) and SpeciesLink (http://splink.cria.org.br/). Finally, we plotted all records on a map of Minas Gerais, alongside existing hydroelectric dams and the ones in the planning stage based on information from the Brazilian Ministry of Mines and Energy (Brasil/Sigel 2011). Details on each record are provided in Table 1.

\section{Results}

According to Turner (2016), P. melanoleuca (Fig. 1) may be identified as about $15 \mathrm{~cm}$ and $11 \mathrm{~g}$, presenting deeply forked tail, glossy blue-black crown and upperparts, black wings and tail, white underparts, with blue-black breastband and blue-black undertail coverts.

We recorded P. melanoleuca at 17 sites in Minas Gerais (Fig. 2). In the São Francisco river basin, new records were obtained in Abaeté, Paraopeba, Santo Antônio and Pará rivers. In Abaeté River, we recorded the species at 7 distinct localities in the municipality of São Gonçalo do Abaeté $\left(18^{\circ} 05^{\prime} 55^{\prime \prime} \mathrm{S}, 045^{\circ} 25^{\prime} 27^{\prime \prime} \mathrm{W}\right)$. On the Paraopeba River, 1 individual was observed upstream of the Retiro

Table 1. Records of Black-collared Swallow (Pygochelidon melanoleuca) from Minas Gerais state, Brazil. Previous records from Barros (2008) and Drummond et al. (2008). ${ }^{*}$ Centro de Coleções Taxonômicas of the Universidade Federal de Minas Gerais, ** roosting site, *** Henrique (2015) and David (2017).

\begin{tabular}{|c|c|c|c|c|c|c|c|}
\hline Source & Records & Date & $\begin{array}{l}\text { Latitude } \\
\text { (S) }\end{array}$ & $\begin{array}{l}\text { Longitude } \\
\text { (W) }\end{array}$ & Municipality & River & $\begin{array}{l}\text { Hydrographic } \\
\text { basin }\end{array}$ \\
\hline $\begin{array}{l}\text { DZUFMG } \\
\text { (DZ5840)* }^{*}\end{array}$ & Previous & Apr. 2008 & $18^{\circ} 48^{\prime} 08^{\prime \prime}$ & $048^{\circ} 09^{\prime} 51^{\prime \prime}$ & Araguari & Araguari & Paranaíba \\
\hline G. Malacco & Previous & Sept. 2006 & $18^{\circ} 3843^{\prime \prime}$ & $048^{\circ} 26^{\prime} 18^{\prime \prime}$ & Araguari & Araguari & Paranaíba \\
\hline G. Malacco & Previous & March, May \& Sept. 2006 & $18^{\circ} 38^{\prime} 51^{\prime \prime}$ & $048^{\circ} 20^{\prime} 02^{\prime \prime}$ & Araguari & Araguari & Paranaíba \\
\hline G. Malacco & Previous & Feb., Apr. \& Sept. 2006 & $18^{\circ} 41^{\prime} 40^{\prime \prime}$ & $048^{\circ} 19^{\prime} 21^{\prime \prime}$ & Araguari & Araguari & Paranaíba \\
\hline G. Malacco & Previous & Apr. \& Sept. 2006 & $18^{\circ} 44^{\prime} 33^{\prime \prime}$ & $048^{\circ} 16^{\prime} 04^{\prime \prime}$ & Araguari & Araguari & Paranaíba \\
\hline G. Malacco** & Previous & Apr. \& Nov. 2006 & $18^{\circ} 45^{\prime} 54^{\prime \prime}$ & $048^{\circ} 15^{\prime} 43^{\prime \prime}$ & Araguari & Araguari & Paranaíba \\
\hline G. Malacco & Previous & March 2012 & $18^{\circ} 47^{\prime} 52^{\prime \prime}$ & $048^{\circ} 10^{\prime} 05^{\prime \prime}$ & Araguari & Araguari & Paranaíba \\
\hline G. Malacco & Previous & Apr. 2007 & $18^{\circ} 48^{\prime} 19^{\prime \prime}$ & $048^{\circ} 09^{\prime} 55^{\prime \prime}$ & Araguari & Araguari & Paranaíba \\
\hline G. Malacco & Previous & March 2012 & $18^{\circ} 48^{\prime} 36^{\prime \prime}$ & $048^{\circ} 09^{\prime} 38^{\prime \prime}$ & Araguari & Araguari & Paranaíba \\
\hline G. Malacco & Previous & Nov. 2006 & $18^{\circ} 48^{\prime} 49^{\prime \prime}$ & $048^{\circ} 09^{\prime} 25^{\prime \prime}$ & Araguari & Araguari & Paranaíba \\
\hline G. Malacco & Previous & May, Nov. \& Dec. 2006 & $18^{\circ} 47^{\prime} 52^{\prime \prime}$ & $048^{\circ} 08^{\prime} 51^{\prime \prime}$ & Araguari & Araguari & Paranaíba \\
\hline G. Malacco & Previous & March \& Oct. 2012 & $18^{\circ} 47^{\prime} 21^{\prime \prime}$ & $048^{\circ} 08^{\prime} 54^{\prime \prime}$ & Araguari & Araguari & Paranaíba \\
\hline G. Malacco & Previous & July \& August 2005 & $18^{\circ} 48^{\prime} 07^{\prime \prime}$ & $048^{\circ} 06^{\prime} 42^{\prime \prime}$ & Araguari & Araguari & Paranaíba \\
\hline G. Malacco & Previous & July \& August 2005 & $18^{\circ} 48^{\prime} 34^{\prime \prime}$ & $048^{\circ} 06^{\prime} 29^{\prime \prime}$ & Araguari & Araguari & Paranaíba \\
\hline $\begin{array}{l}\text { Cemig/Neoinvest } \\
(2012)\end{array}$ & New & Sept. \& Nov. 2009 & $18^{\circ} 10^{\prime} 10^{\prime \prime}$ & $047^{\circ} 27^{\prime} 35^{\prime \prime}$ & Abadia dos Dourados & Paranaíba & Paranaíba \\
\hline G. Malacco & New & Sept. 2013 & $18^{\circ} 12^{\prime} 56^{\prime \prime}$ & $047^{\circ} 34^{\prime} 08^{\prime \prime}$ & Abadia dos Dourados & Paranaíba & Paranaíba \\
\hline W. Nogueira & New & Feb. 2011 & $18^{\circ} 06^{\prime} 49^{\prime \prime}$ & $045^{\circ} 27^{\prime} 51^{\prime \prime}$ & São Gonçalo do Abaeté & Abaeté & São Francisco \\
\hline W. Nogueira & New & Feb. 2011 & $18^{\circ} 06^{\prime} 23^{\prime \prime}$ & $045^{\circ} 27^{\prime} 32^{\prime \prime}$ & São Gonçalo do Abaeté & Abaeté & São Francisco \\
\hline W. Nogueira & New & Feb./2011 & $18^{\circ} 05^{\prime} 55^{\prime \prime}$ & $045^{\circ} 25^{\prime} 27^{\prime \prime}$ & São Gonçalo do Abaeté & Abaeté & São Francisco \\
\hline W. Nogueira & New & Feb. 2011 & $18^{\circ} 11^{\prime} 59^{\prime \prime}$ & $045^{\circ} 38^{\prime} 38^{\prime \prime}$ & São Gonçalo do Abaeté & Abaeté & São Francisco \\
\hline W. Nogueira & New & Feb. 2011 & $18^{\circ} 14^{\prime} 30^{\prime \prime}$ & $045^{\circ} 40^{\prime} 05^{\prime \prime}$ & São Gonçalo do Abaeté & Abaeté & São Francisco \\
\hline W. Nogueira & New & Feb. 2011 & $18^{\circ} 23^{\prime} 37^{\prime \prime}$ & $045^{\circ} 43^{\prime} 54^{\prime \prime}$ & São Gonçalo do Abaeté & Abaeté & São Francisco \\
\hline $\begin{array}{l}\text { G. Silva and G. } \\
\text { Salvador }\end{array}$ & New & Jan. 2015 & $19^{\circ} 44^{\prime} 21^{\prime \prime}$ & $044^{\circ} 53^{\prime} 29^{\prime \prime}$ & Conceição do Pará & Pará & São Francisco \\
\hline F. Carvalho & New & March 2016 & $19^{\circ} 29^{\prime} 21^{\prime \prime}$ & $045^{\circ} 00^{\prime} 46^{\prime \prime}$ & Pitangui & Pará & São Francisco \\
\hline L. Carrara & New & June 2004 & $18^{\circ} 44^{\prime} 52^{\prime \prime}$ & $045^{\circ} 01^{\prime} 26^{\prime \prime}$ & Três Marias & São Francisco & São Francisco \\
\hline A. Macarrão & New & Jan. 2011 & $18^{\circ} 53^{\prime} 18^{\prime \prime}$ & $044^{\circ} 46^{\prime} 42^{\prime \prime}$ & Pompéu & Paraopeba & São Francisco \\
\hline T. Sousa & New & June 2014 & $19^{\circ} 00^{\prime} 48^{\prime \prime}$ & $044^{\circ} 44^{\prime} 23^{\prime \prime}$ & Pompéu & Paraopeba & São Francisco \\
\hline E. Alteff & New & August 2014 & $17^{\circ} 37^{\prime} 05^{\prime \prime}$ & $045^{\circ} 39^{\prime} 15^{\prime \prime}$ & João Pinheiro & Santo Antônio & São Francisco \\
\hline $\begin{array}{l}\text { WA1876714, } \\
\text { WA2506603*** }\end{array}$ & New & Oct. 2015 \& March 2017 & $16^{\circ} 11^{\prime} 14^{\prime \prime}$ & $040^{\circ} 41^{\prime} 46^{\prime \prime}$ & Almenara & Jequitinhonha & Jequitinhonha \\
\hline W. Nogueira & New & Jan. 2015 \& Oct. 2015 & $16^{\circ} 11^{\prime} 12^{\prime \prime}$ & $040^{\circ} 41^{\prime} 44^{\prime \prime}$ & Almenara & Jequitinhonha & Jequitinhonha \\
\hline J. F. Pacheco & New & Oct. 2005 & $16^{\circ} 25^{\prime} 59^{\prime \prime}$ & $040^{\circ} 58^{\prime} 59^{\prime \prime}$ & Almenara & Jequitinhonha & Jequitinhonha \\
\hline
\end{tabular}




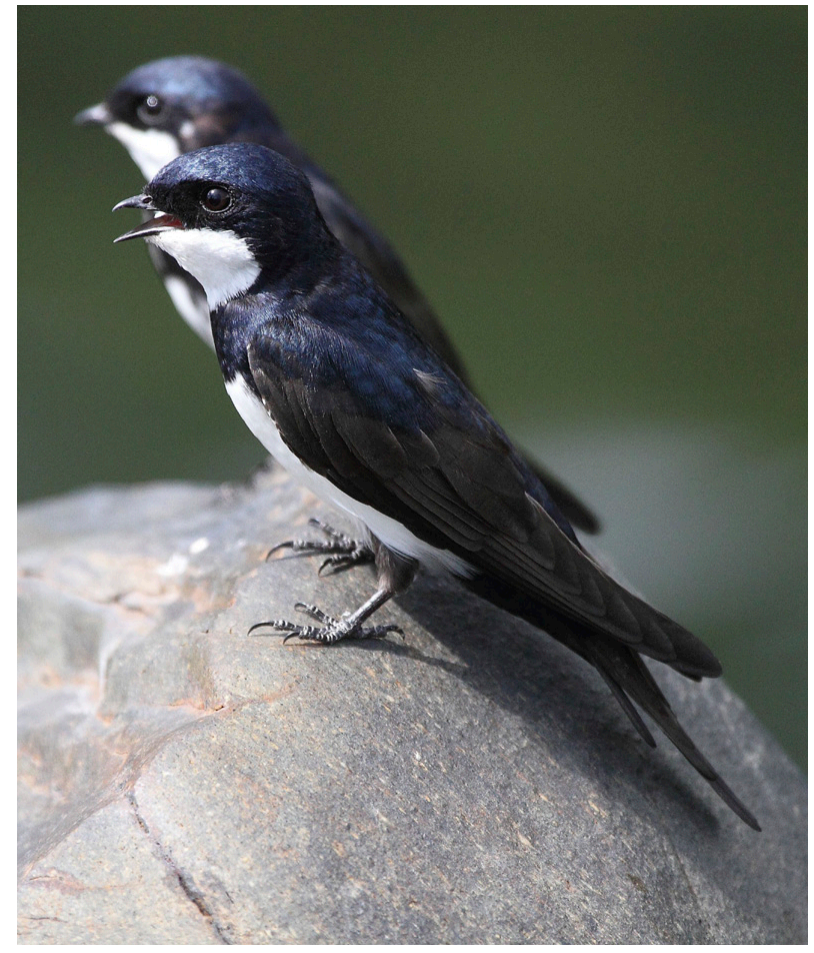

Figure 1. Pygochelidon melanoleuca (Black-collared Swallow) on exposed rocks in the Pará River ( $\left.19^{\circ} 44^{\prime} 21^{\prime \prime} \mathrm{S}, 044^{\circ} 53^{\prime} 29^{\prime \prime} \mathrm{W}\right)$, municipality of Conceição do Pará, state of Minas Gerais, Brazil, on 23 January 2015. Photograph by Gilberto N. Salvador.

Baixo dam $\left(18^{\circ} 53^{\prime} 18^{\prime \prime} \mathrm{S}, 044^{\circ} 46^{\prime} 42^{\prime \prime} \mathrm{W}\right)$ on the border of the municipalities of Curvelo and Pompéu (A. Macarrão, pers. comm.). Three more individuals were recorded along the same river, at Cachoeira do Choro $\left(19^{\circ} 00^{\prime} 48^{\prime \prime}\right.$ S, $044^{\circ} 44^{\prime} 23^{\prime \prime} \mathrm{W}$ ) in the municipality of Pompéu (T. Souza pers. comm.). In Santo Antônio River (17 $37^{\prime} 05^{\prime \prime}$ S, $\left.045^{\circ} 39^{\prime} 15^{\prime \prime} \mathrm{W}\right)$, a tributary of the Paracatu River, 6 individuals were observed in the municipality of João Pinheiro (E. Alteff, pers. comm.). This species was also observed in Pará River, in municipalities of Conceição do Pará $\left(19^{\circ} 44^{\prime} 21^{\prime \prime}\right.$ S, 044 53'29" W, Fig. 1) and Pitangui $\left(19^{\circ} 29^{\prime} 21^{\prime \prime} \mathrm{S}, 045^{\circ} 00^{\prime} 46^{\prime \prime} \mathrm{W}\right)$ (F. Carvalho pers. comm.). There is also a record from the Três Marias reservoir in 2004 , in the municipality of Três Marias $\left(18^{\circ} 44^{\prime} 52^{\prime \prime} \mathrm{S}\right.$, $\left.045^{\circ} 01^{\prime} 26^{\prime \prime} \mathrm{W}\right)$ (L. Carrara pers. comm.).

In the Jequitinhonha river basin, records of $P$. melanoleuca are scarce and restricted to the river's main channel in the municipality of Almenara $\left(16^{\circ} 25^{\prime} 59^{\prime \prime} \mathrm{S}\right.$, $\left.040^{\circ} 58^{\prime} 59^{\prime \prime} \mathrm{W}\right)$, where 4 individuals were observed in 2005 (F. Pacheco pers. comm.), and several others were recorded under a bridge between the city of Almenara and a federal road (BR-367) in January 2015 and October 2016 (16¹1'12" S, 040 41'44" W).

In the Paranaíba river basin, $P$. melanoleuca was recorded from September to November 2009 (Cemig/ Neoinvest 2012) and September 2013 along the central section of the Paranaíba River on the border of the states of Minas Gerais and Goiás $\left(18^{\circ} 10^{\prime} 10^{\prime \prime} \mathrm{S}, 047^{\circ} 27^{\prime} 35^{\prime \prime} \mathrm{W}\right.$; $\left.18^{\circ} 12^{\prime} 56^{\prime \prime} \mathrm{S}, 047^{\circ} 34^{\prime} 08^{\prime \prime} \mathrm{W}\right)$. Until recently P. melanoleuca was only known in Minas Gerais from the Araguari river basin, which is part of the Paranaíba river basin
(Barros 2008, Drummond et al. 2008). In July and August 2005 and from February to May and September to December 2006, we observed the species along several lotic sections of the Araguari River on the border of the Uberlândia and Araguari municipalities. In April and November 2006, 150 individuals were observed roosting under a railway bridge of the Araguari River (Table 1). However, in March and October 2012 no individuals were observed at the same lotic sections and the roosting site. At same period some individuals were observed in the residual flow river stretch, that is, the river stretch between dam and powerhouse, of the Amador Aguiar I Hydroeletric Power Plant.

\section{Discussion}

All river basins in which new records of $P$. melanoleuca were obtained were previously visited by ornithologists but there were no previous records of this species for these sites (e.g., Kirwan et al. 2001, 2004, Vasconcelos and Silva 2004, Vasconcelos et al. 2004, 2005, Vasconcelos and D'Angelo Neto 2007, Silveira 2009, Diniz et al. 2012, Schunck et al. 2012, Carrara et al. 2013). This lack of previous records might either reflect recent range expansion or undersampling of the specific microhabitats, rarely visited by ornithologists, required by this species. Thus, unless the exact river sections with suitable and well preserved microhabitats used by P. melanoleuca are visited, the chances of recording the species are low.

Most of the river basins where the species occurs in Minas Gerais are considered suitable for hydroelectric dam construction, which represents a major long-term threat. The construction of hydroelectric dams will likely flood rocky outcrops that are required by this species (Batista et al. 2012, Lees et al. 2016) and likely lead to local extinctions. In the upper portion of the Paranaíba basin (specifically on the Paranaíba and São Marcos rivers) 4 new dams are planned for a near future (ANEEL 2003, 2004). In the São Francisco basin, all rivers mentioned here (i.e., Abaeté, Santo Antônio, Pará and Paraopeba rivers) have dams under construction or already complete. In the Jequitinhonha basin, 7 new dams are expected to be built on the main river channel (Fig. 2).

The river sections targeted for dam constructions often present steep fluvial gradients and rapids which are the main habitat of P. melanoleuca. Thus, the construction of additional dams may likely lead to dramatic declines of these recently discovered populations, as has potentially happened on the Araguari River with the implementation of 2 dams (Biovet 2012). Currently there are approximately 136 hydropower plants in the state of Minas Gerais (ANA 2016), and another 45 new large hydroelectric ("Usina Hidrelétrica" or "UHE", in Portuguese) and 335 new small hydropower plants ("Pequena Central Hidrelétrica" or "PCH", in Portuguese) are expected to be built in this state in the next 20 years, encompassing 8 river basins, including the São Francisco, Paranaíba and Jequitinhonha Rivers (SEMAD 2007). 


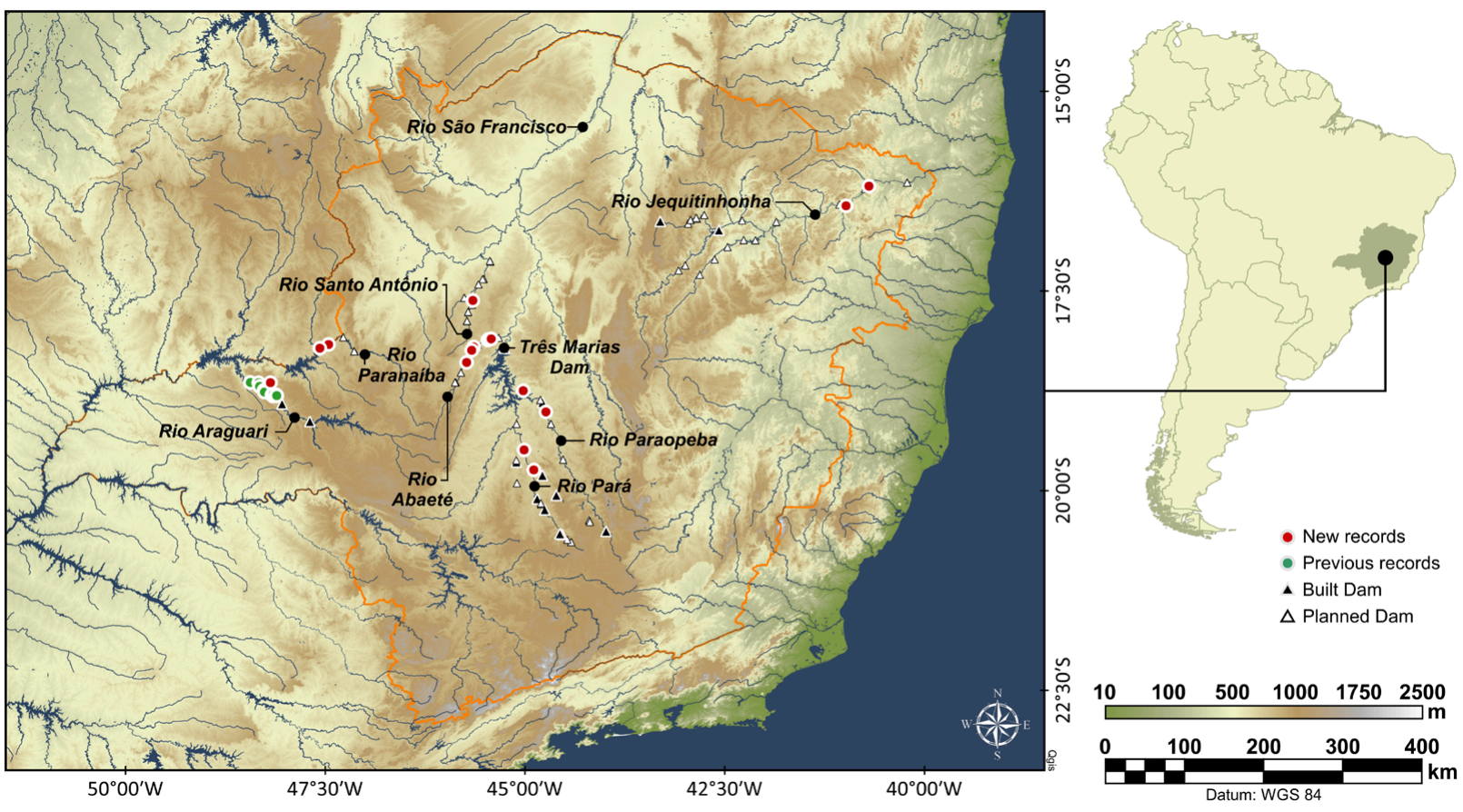

Figure 2. New (red) and previous (green circles) of Pygochelidon melanoleuca (Black-collared Swallow) from the state of Minas Gerais. Existing (black triangle) and planned dams (white triangle) according to Brasil/Sigel (2011) are also shown.

Importantly, in most cases the hydroelectric projects are licensed and assessed individually, neglecting cumulative negative effects of multiple dams built in the same river on the biodiversity. In this context, the implementation of such individual dams is commonly considered as "low impact" despite the lack of investigation of such cumulative impacts. A comprehensive analysis of the impacts should take into account the entire river basin in order to better understand and forecast the extent of the effects of multiple dams on animal populations. Such comprehensive studies would allow more effective mitigation or compensatory measures (MMA 2006, Lees et al. 2016), such as the establishment of dam-free river sections.

In summary, the records compiled here increase the known range of $P$. melanoleuca in Minas Gerais. Previous knowledge gaps are likely explained by the patchy distribution of the species as well as lack of sampling on the species habitat. We expect further field surveys to reveal other populations, especially in other tributaries of São Francisco, Paranaíba and Jequitinhonha rivers and also in other river basins where even the main channel remain poorly sampled, like the Mucuri River. We also encourage research on the basic ecology of the species and the potential effects of dams its population viability.

\section{Acknowledgements}

We are grateful to Alexandre Aleixo and Fátima Lima (MPEG), Mário Cohn-Haft and Ingrid Macedo (INPA), Thiago Vernaschi (MUZUSP) and Marcelo Vasconcelos (DZUFMG) for providing information on specimens deposited in collections; to Marcelo Vasconcelos, Jeferson Vizentin-Bugoni and an anonymous reviewer for valu- able contributions to the manuscript; to Thiago Souza, Arthur Macarrão, Fernando Carvalho, Lucas Carrara, José Fernando Pacheco and Eduardo Alteff for providing some records; to Alexander Lees for reviewing the text; and to Companhia Energética de Minas Gerais (CEMIG - P\&D 455) and Coordenação de Aperfeiçoamento de Pessoal de Nível Superior (CAPES) for financial support.

\section{Authors' Contributions}

GAS, GNS, GBM and WN collected the data; GAS, GNS and SMA wrote the text; all authors revised the text; GNS took the photograph and generated the map.

\section{References}

ANA (Agência Nacional de Águas) (2016) Relatório de Segurança de Barragens 2015.Agência Nacional de Águas, Brasília, 168 pp. http://arquivos.ana.gov.br/cadastros/barragens/seguranca/RelatorioSegurancaBarragens_2015.pdf. Accessed on: 2017-01-04.

ANEEL (Agência Nacional de Energia Elétrica) (2003) Despacho número 910, de 26 de novembro de 2003. http://www2.aneel.gov. br/cedoc/dsp2003910.pdf. Accessed on: 2017-6-15.

ANEEL (Agência Nacional de Energia Elétrica) (2014) Despacho número 1.451, de 9 de maio de 2014. http://www2.aneel.gov.br/ cedoc/dsp20141451ti.pdf. Accessed on: 2017-6-15.

Barros LP (2008) Monitoramento de Atticora melanoleuca - andorinha-de-coleira durante e após a formação do reservatório da UHE Amador Aguiar II, (Bacia do Paranaíba - Rio Araguari - MG). Livro de Resumos do XVI Congresso Brasileiro de Ornitologia. Universidade Federal do Tocantins, Sociedade Brasileira de Ornitologia, Grupo de Pesquisa em Ecologia e Conservação de Aves (ECOAVES-UFT), Palmas, 458 pp. http://www.uff.br/biodiversidade/images/stories/arquivos/ArtigosMergus/res_xvi_cbo.pdf. Accessed on: 2016-01-08.

Batista BMF, Sánchez DCM, Silva JV, Martinez DT, Pasa MC (2012) 
Revisão dos impactos ambientais gerados na fase de instalação das hidrelétricas: uma análise da sub-bacia do Alto Juruena-MT. Biodiversidade 11 (1): 69-85.

Biovet (Biovet Planejamento e Serviços Ambientais Ltda) (2012) Monitoramento de Pygochelidon melanoleuca - Andorinha-de-coleira na área diretamente afetada pelo complexo energético Amador Aguiar (Setembro/2006 a Novembro/2011). Biovet Planejamento e Serviços Ambientais Ltda, Belo Horizonte, 57 pp.

Brasil/Sigel (2011) Sistema de Informações Georreferenciadas do Setor Elétrico. http://sigel.aneel.gov.br. Accessed on: 2011-2-12.

BirdLife International (2016) Pygochelidon melanoleuca. The IUCN Red List of Threatened Species 2016. http://www.iucnredlist.org/ details/22712140/0. Accessed on: 2017-4-2.

Carrara LA, Faria LCP, Garcia FI, Antas PTZ (2013) Avifauna da Estação Ecológica Estadual de Acauã e chapadas do alto vale do rio Jequitinhonha: ecótono de três biomas em Minas Gerais. Ornithologia 5 (2): 58-77.

Cemig/Neoinvest (2012) Estudo de Impacto Ambiental do Aproveitamento Hidrelétrico de Davinópolis. Água e Terra Planejamento Ambiental Ltda, Patos de Minas, 451 pp.

COPAM(Conselho Estadual de Política Ambiental)(2010) Lista de Espécies Ameaçadas de Extinção da Fauna do Estado de Minas Gerais. http://www.siam.mg.gov.br/sla/download.pdf?idNorma=13192. Accessed on: 2015-10-14.

David PM (2017) WA2506603, Pygochelidon melanoleuca (Wied, 1820). Wiki Aves-A Enciclopédia das Aves do Brasil. http:// www.wikiaves.com/2506603. Accessed on: 2017-5-6.

Diniz MG, Mazzoni LG, D’Angelo Neto S, Vasconcelos MF, Perillo A, Benedicto GA (2012) Historical synthesis of the avifauna from the Rio São Francisco basin in Minas Gerais, Brazil. Revista Brasileira de Ornitologia 20 (3): 329-349.

Drummond GM, Machado ABM, Martins CS, Mendonça MP, Stehmann JR (2008) Listas Vermelhas das Espécies da Fauna e da Flora Ameaçada de Extinção em Minas Gerais. Fundação Biodiversitas, Belo Horizonte, http://www.biodiversitas.org.br/cdlistavermelha/ default.asp. Acessed on: 2016-01-08.

Henrique L (2015) WA1876714, Pygochelidon melanoleuca (Wied, 1820). Wiki Aves-A Enciclopédia das Aves do Brasil. http:// www.wikiaves.com/1876714. Accessed on: 2017-4-4.

Kirwan GM, Barnett JM, Minns J (2001) Significant ornithological observations from the Rio São Francisco valley, Minas Gerais, Brazil, with notes on conservation and biogeography. Revista Brasileira de Ornitologia 9 (2): 145-161.

Kirwan GM, Barnett JM, Vasconcelos MF, Raposo MA, D’Angelo Neto S, Roesler I (2004) Further comments on the avifauna of the middle São Francisco Valley, Minas Gerais, Brazil. Bulletin of the British Ornithologists' Club 124 (3): 207-220.

Lees AC, Peres CA, Fearnside PM, Schneider M, Zuanon JAS (2016) Hydropower and the future of Amazonian biodiversity. Biodi- versity and Conservation 25: 451-466. https://doi.org/10.1007/s 10531-016-1072-3

MMA (Ministério do Meio Ambiente) (2006) Avaliação ambiental integrada de bacia hidrográfica. Ministério do Meio Ambiente, Brasília, 302 pp. http://www.mma.gov.br/estruturas/sqa_pnla/_arquivos/ sqa_3.pdf. Accessed on: 2016-12-02.

MMA (Ministério do Meio Ambiente) (2015) Resultado da Avaliação do Estado de Conservação das Aves Brasileiras Ciclo 2010-2014. http://www.icmbio.gov.br/cemave/images/stories/oquefazemos/ result_avaliac_2010-2014.pdf. Accessed on: 2016-10-13.

Ridgely RS, Tudor G (1989) The Birds of South America: The Oscine Passerines. University of Texas Press, Austin, 596 pp.

Schunck F, Piacentini VQ, Souza EA, Sousa AEBA, Rego MA, Albano C, Nunes MFC, Favaro FL, Neto IS; Mariano EF, Lima DM, LasCasas FMG, Rodrigues RC, Neto FPF (2012) Birds of the lower middle São Francisco River. Revista Brasileira de Ornitologia 20 (3): 350-364.

SEMAD (Secretaria do Estado e Meio Ambiente e Desenvolvimento Sustentável) (2007) Governo de Minas Apresenta Estudo para Planejamento Energético. http://www.meioambiente.mg.gov.br/ noticias/1/176-governo-de-minas-apresenta-estudo-para-planejamento-energetico. Access on: 2016-10-15.

Sick H (1997) Ornitologia Brasileira.Nova Fronteira, Rio de Janeiro, $862 \mathrm{pp}$.

Silveira LF (2009) Aves.In: Drummond GM, Martins CS, Greco MB, Vieira F (Eds) Biota Minas: Diagnóstico do Conhecimento sobre a Biodiversidade no Estado de Minas Gerais - Subsídio ao Programa Biota Minas. Fundação Biodiversitas, Belo Horizonte, 281-295 http://www.biodiversitas.org.br/biotaminas/publicacao/biotaminas.pdf. Accessed on: 2016-09-29.

Straube FC, Urben-Filho A, Cândido-Jr JF (2004) Novas informações sobre a avifauna do Parque Nacional do Iguaçu (Paraná). Atualidades Ornitológicas 120: 10-28.

Turner A (2016) Black-collared Swallow (Atticora melanoleuca). In: Del Hoyo J, Elliott A, Sargatal J, Christie DA, Juana E (Eds) Handbook of the Birds of the World Alive. Lynx Edicions, Barcelona. http://www.hbw.com/node/57724. Accessed on: 2016-08-06.

Vasconcelos MF, Silva JF (2004) Limite norte da distribuição do pichororé Synallaxis ruficapilla (Aves, Furnariidae). Boletim Museu Biologia Mello Leitão 17: 65-68.

Vasconcelos MF, D'Angelo-Neto S, Maldonado-Coelho M (2004) New noteworthy occurrences of the Wied's Tyrant Manakin (Neopelma aurifrons) in Brazil. Ornitología Neotropical 15: 547-548.

Vasconcelos MF, D’Angelo-Neto S, Nemésio A (2005) Observações sobre o Rei-dos-tangarás Chiroxiphia caudata X Antilophia galeata em Minas Gerais, Brasil. Cotinga 23: 65-69.

Vasconcelos MF, D’Angelo-Neto S (2007) Padrões de distribuição e conservação da avifauna na região central da Cadeia do Espinhaço e áreas adjacentes, Minas Gerais, Brasil. Cotinga 28: 27-44. 